\title{
КОМПЕТЕНТНІСНИЙ ПІДХІД У ПІДГОТОВЦІ СТУДЕНТІВ-МЕДИКІВ
}

\author{
М. М. Рожко, Г. М. Ерстенюк, В. В. Капечук, М. О. Іванців, В. М. Сенчій \\ ДВНЗ “Івано-Франківський національний медичний університет”
}

\section{COMPETENCE APPROACH IN TRAINING OF MEDICAL STUDENTS

\author{
M. M. Rozhko, H. M. Erstenyuk, V. V. Kapechuk, M. O. Ivantsiv, V. M. Senchiy \\ SHEI "Ivano-Frankivsk National Medical University"
}

\begin{abstract}
Експерти Ради Європи вказують на цілу низку компетенцій, якими повинен оволодіти випускник вищого навчального закладу: соціальні, комунікативні, інформаційні, навчальні. Для реалізації професійно мотивованої діяльності студентів медичних (фармацевтичних) навчальних закладів, на нашу думку, важливим є створення навчально-практичних центрів (НПЦ), які дозволяють оволодіти необхідними практичними навичками. За рішенням Вченої ради, в ІваноФранківському національному медичному університеті (ІФНМУ) створені та активно функціонують упродовж чотирьох років НПЦ: “Медицина”, “Центр слуху”, “Анатомія”, “Військово-медична підготовка”, “Стоматологія”, “Фармація”, “Хроматографічний аналіз”, на базі яких студенти, лікарі-інтерни мають можливість опанувати практичні навички та підготуватись до державної атестації, а лікарі загальної практики - сімейної медицини - вдосконалювати свої практичні можливості. 3 метою якісного засвоєння студентами практичних навичок та повноцінного контролю за їх виконанням в університеті розроблено Індивідуальний план практичної підготовки студента. На нашу думку, розвиток системи навчально-практичних центрів $з$ належним матеріальним, методичним та інформаційним забезпеченням є одним із шляхів реалізації компетентнісного підходу в підготовці майбутніх фахівців медичної та фармацевтичної сфери.
\end{abstract}

Council of Europe experts point out to a number of competencies that should master the graduate student: social, communicational, informational, educational. To implement professionally motivated students of medical (pharmaceutical) educational institutions, in our opinion, it is important to create learning-practical centers (LPC), which allow acquiring the necessary practical skills. By decision of the Academic Council in Ivano-Frankivsk National Medical University (IFNMU) actively operating for four years our LPCs: "Medicine”, “Center for Hearing”, “Anatomy”, “Military Medical Training”, "Stomatology", "Pharmacy" "Chromatographic analysis" based on which students, doctors, interns have the opportunity to learn practical skills and prepare for state certification, and doctors - general practitioners of family medicine to improve their practical capabilities. In order to quality mastering practical skills and full control over their performance at the University developed a Individual plan of students' practical skills. In our opinion, the development of learning and practical centers with adequate material, methodological and information support is one of the ways to implement competency approach in training future professionals of medical and pharmaceutical industry.

Вступ. Компетентнісний підхід, виходячи із Національного освітнього глосарія (2014), є ключовим методологічним інструментом реалізації цілей Болонського процесу та за своєю сутністю є студентоорієнтованим $[1,10]$. Експерти Ради Європи вказують на цілу низку компетенцій, якими повинен оволодіти випускник вищого навчального закладу: соціальні, комунікативні, інформаційні, навчальні [5]. Навчальні компетенції визначають необхідність освіти впродовж усього життя і лежать в основі безперервної професійної освіти, що особливо важливо для фахівців медичної сфери, покладені в основу кваліфікації випускника, відображені в освітньо-кваліфікаційній характеристиці (OKX), що визначає готовність до майбутньої професійної діяльності [5, 7]. Забезпечення компетент-

(c) М. М. Рожко, Г. М. Ерстенюк, В. В. Капечук та ін. нісного підходу потребує системи дидактично та методично оформленого навчального матеріалу [8]. Важливими при цьому є визначення мети і змісту навчання; забезпечення умов для реалізації освітнього процесу; удосконалення форм, методів і засобів навчання; створення ефективної організації навчання та нових технологій навчання [6]. Застосування системного, діяльнісного та особистісно орієнтованого підходів до підготовки майбутнього медика чи фармацевта $є$ важливою складовою в організації освітнього процесу [2-4]. Такий підхід зумовлює необхідність побудови навчального процесу як активної навчально-пізнавальної діяльності студента. Для реалізації професійно мотивованої діяльності студентів медичних (фармацевтичних) навчальних закладів, на нашу думку, важливим $€$ створення навчально-практичних центрів (НПЦ), 
які дозволяють оволодіти необхідними практичними навичками $[1,9]$.

Основна частина. За рішенням Вченої ради, в Івано-Франківському національному медичному університеті (ІФНМУ) створені та активно функціонують упродовж чотирьох років НПЦ: “Медицина”, “Центр слуху”, “Анатомія”, “Військово-медична підготовка”, “Стоматологія”, “Фармація”, “Хроматографічний аналіз”, на базі яких студенти, лікарі-інтерни мають можливість опанувати практичні навички та підготуватись до державної атестації, а лікарі загальної практики - сімейної медицини - вдосконалювати свої практичні можливості [2-4].

НПЦ “Медицина” має такі зали: “Догляд за хворими”, “Зондові маніпуляції”, “Зал ін’єкційної техніки”, “Функціональні методи дослідження. Невідкладна допомога”, зали для опрацювання практичних навичок з анестезіології та інтенсивної терапії, акушерства та гінекології, педіатрії. Центр укомплектований відповідним матеріально-технічним обладнанням: манекеном для проведення ШВЛ та масажу серця під контролем комп'ютера, манекеном для проведення серцево-легеневої реанімації, манекенами, велоергометрами Lifecycle 9500R та “Ритм”, комп'ютерним спірометром SpiroCom, УЗД-апаратом UltraMark 4 plus, плазмовою панеллю для виведення результатів ЕХО та УЗД, апаратом для ультрасонографії, ендоскопом СМ-9, фіброезофагоскопом “Olimpus”, ацидогастрографом АГ-1рН-М, електрокардіографом ЭК1Т-1/3-07, бінокулярними мікроскопами “Мікромед” XS-3320 з відеопідсистемою, фантомами для проведення внутрішньовенних та внутрішньом'язових ін’єкцій, біохімічними аналізаторами “Apel” - 1 од., глюкометрами портативними, приладами для вимірювання рівня холестерину в крові. В залі “Догляд за хворими” студенти відпрацьовують принципи догляду за лежачим хворим, включно з профілактикою пролежнів. Алгоритмами техніки виконання шлунково-кишкового зондування з діагностичною та лікувальною метою студенти можуть оволодіти в залі “Зондові маніпуляції”. Заняття на тему “Алгоритм техніки виконання внутрішньошкірних, підшкірних ін’єкцій” зі студентами проводяться в приміщенні “Зал ін’єкційної техніки”. У залі “Функціональні методи дослідження. Невідкладна допомога” функціонує діагностична система “Corival” (велоергометр, ЕКГ-апарат, комп’ютер, програмне забезпечення) для оцінки толерантності до фізичного навантаження та виконання тренувальних програм. Студенти відпрацьовують етапи серцево-легеневої реанімації, а також удосконалюють навички надання медичної допомоги при невідкладних станах у внутрішній медицині. Тренінгові навчальні кімнати обладнані засобами різного медичного устаткування, які дають можливість студентам опанувати методики проведення пікфлоуметрії та комп’ютерної спірометрії, запис та розшифрування електрокардіограм, вимірювання АТ та оцінювання серцево-судинного ризику, вимірювання рівня глікемії та проведення проби 3 навантаженням, вимірювання рівня холестерину крові, вивчення принципу роботи ендоскопа та проведення внутрішньопорожнинної комп’ютерної рН-метрії, основи роботи з УЗД-апаратом та проведення УЗД органів черевної порожнини. Для кращого засвоєння практичних навичок студентами медичного факультету та факультету підготовки іноземних громадян на кафедрі загальної практики (сімейної медицини), фізичної реабілітації та спортивної медицини створено тренінговий навчальний зал. Центр постійно поповнюється наглядними стендами, на яких подані найбільш типові відхилення на ЕКГ, представлені ехограми жовчного міхура, печінки, підшлункової залози, нирок, щитоподібної залози та фотографії найбільш типових змін крові.

Кафедра анестезіології та інтенсивної терапії укомплектована манекенами для проведення ШВЛ і масажу серця під контролем комп’ютера та муляжем для катетеризації центральних вен, де студенти відпрацьовують етапи серцево-легеневої реанімації, а також удосконалюють навики надання медичної допомоги при невідкладних станах.

На кафедрах акушерства та гінекології, педіатрії, дитячої хірургії та пропедевтики педіатрії організовані тренінгові навчальні кімнати, які обладнані сучасними муляжами, фантомами електрокардіографами, ляльками педіатричними, тренажерами для проведення ін’єкцій, наборами для промивання шлунка, проведення катетеризації сечового міхура тощо.

У клінічній амбулаторії с. Іваниківка, яка віддалена від м. Івано-Франківська на 18 км, функціонує повністю оснащена сільська лікарська амбулаторія. Студенти, в реальних умовах, можуть навчитися заповнювати лікувально-звітну документацію: санаторно-курортні карти, рецепти, талони амбулаторного пацієнта ф-025-6-1/о, складати особистий план роботи сімейного лікаря та формувати річний звіт закладу тощо. Завдяки наявності телемедичних технологій у НПЦ є можливість надавати кваліфі- 
ковану медичну допомогу населенню із залученням провідних спеціалістів університету. Технології реалізовані на базі комунікаційного комплексу університету, котрий базується на хмарі Office365.

На базі НПЦ функціонують 3 комп’ютерні класи із загальною кількістю 35 комп’ютерів. На комп’ютерах встановлено програмне забезпечення компанії Littmann Auscultaion, що дає змогу студентам змоделювати серцеву патологію і почути серцеві та легеневі шуми при різноманітних розповсюджених та рідкісних захворюваннях. Запроваджена методика доступу до контролюючих систем iз використанням планшетів на базі OC “Android” значно підвищила мобільність студентів в НПЦ та швидкість доступу до інформації, з метою вироблення навички прийняття правильного рішення.

НПЦ “Стоматологія” організований на базі стоматологічного факультету та Центру стоматології університетської клініки ІФНМУ й об’єднує 15 фантомних та клінічних кімнат різного функціонального призначення, де студенти мають можливість опрацьовувати практичні навички 3 різних розділів профільних стоматологічних дисциплін, одночасно може прийняти 162 особи. Площа всіх приміщень НПЦ “Стоматологія” становить 301,8 м². Кімнати НПЦ “Стоматологія” використовуються для проведення практичних занять зі студентами та лікарями-інтернами, консультацій, самостійної роботи студентів під керівництвом викладачів, підготовки до Державної атестації випускників, складання студентами практичної частини підсумкових модульних контролів зі стоматологічних дисциплін. У фантомному класі 3D-технологій встановлено апарат для прицільної рентгенографії зубів і ортопантомограф для отримання розгорнутих знімків однієї чи обох щелеп. В навчальній кімнаті є також рідкокристалічний екран, куди за допомогою комп’ютера, під’єднаного до внутрішньої Інтранет-мережі стоматологічного корпусу, виводяться реальні рентгенологічні зображення щелеп пацієнтів з бази даних знімків, отриманих у рентгенкабінеті Центру стоматології. У кабінеті можна вивчити методику виконання рентгенологічних досліджень, а також провести комп’ютерне планування та 3D-моделювання ходу оперативного втручання з приводу дентальної та щелепнолицевої імплантації. Кабінет невідкладної допомоги оснащений обладнанням і муляжами, які дають змогу оволодіти методиками надання екстреної та невідкладної медичної допомоги (штучна вентиляція легень, непрямий масаж серця), а також виконання загально-медичних маніпуляцій, передбачених OKX і ОПП та вимогами Державної атестації випускників стоматологічного факультету. Фантомний клас кафедри хірургічної стоматології має 10 робочих місць, кожне з яких обладнане стоматологічним фантомом з імітаторами верхньої та нижньої щелеп і штучними зубами, які можна виймати і встановлювати у відповідні лунки на цих щелепах, необхідним хірургічним інструментарієм для вивчення та засвоєння методик екстракції різних груп зубів. Тут також вивчаються особливості проведення анестезій при видаленні зубів. Ливарня входить до складу зуботехнічної лабораторії Центру стоматології університетської клініки, де студенти та інтерни навчаються технічного виконання етапів литва металів при виготовленні суцільнолитих елементів різних ортопедичних конструкцій. Клінічний зал дентальної імплантації оснащений усім необхідним обладнанням та інструментарієм для виконання хірургічного втручання при проведенні дентальної імплантації. Клінічна лабораторія Центру стоматології дозволяє опанувати практичні навички збору матеріалу та виконання аналізів крові, реакції мікропреципітації, швидких тестів на ВІЛ, пародонтологічних проб, визначення мікрострумів у порожнині рота, цитологічних досліджень. Кімната профілактики стоматологічних захворювань обладнана макетами щелеп, засобами гігієни ротової порожнини, фантомами; тут студенти проводять гігієнічне навчання та виховання, демонструють дітям, що відвідують дитячого стоматолога, правила та послідовність чищення зубів, заходи та засоби догляду за ротовою порожниною, виконують професійну гігієну порожнини рота. У фантомному класі препарування твердих тканин зубів створено 8 робочих місць, кожне 3 яких, крім навчальних фантомів, обладнане портативною стоматологічною установкою з мікромотором та турбінним наконечником. У даній залі студенти засвоюють методики препарування твердих тканин зубів під різні види штучних коронок, методики препарування каріозних порожнин різних класів, використання різних видів пломбувальних матеріалів та методики пломбування каріозних порожнин. Фантомна кімната дентальної імплантації оснащена мультимедійним проектором, екраном, наборами для проведення стоматологічної імплантації компаній “Alfa-Bio”, “U-impl”, “Nobel”, де студенти можуть виконувати різні методики імплантації на фантомних моделях. Кожне робоче місце забезпечене фантомною моделлю з різним типом 
твердості кістки та імітації слизової, абатментами, трансферами та імплантатами.

У кімнаті виконання лабораторних етапів виготовлення ортопедичних конструкцій студенти оволодівають практичними навичками виконання зуботехнічних етапів виготовлення незнімних і знімних конструкцій зубних протезів, а також вивчають обладнання зуботехнічної лабораторії, матеріалів та інструментарію, що використовується в роботі зубного техніка.

Практичні навички з виготовлення сучасних конструкцій знімних бюгельних протезів студенти опрацьовують у кабінеті бюгельного протезування, який оснащений паралелометрами, фрезерувальним апаратом та обладнанням, що дозволяє виготовляти як фантомні, так і “живі” роботи 3 бюгельного протезування, засвоювати методики виготовлення сучасних замкових, телескопічних і кнопкових фіксуючих елементів. Кабінет комп’ютерної томографії оснащений сучасним апаратом, де виконуються методики спіральної томографії. У кабінеті функціональної діагностики щелепно-лицевої ділянки встановлено потужний персональний комп'ютер, оснащений відеокартою з підтримкою двох графічних моніторів, який дозволяє швидко та точно обробляти поставлені перед ним завдання та зберігати інформацію в базах даних до 100 тис. досліджень. До системного блоку приєднуються такі апарати, як електронейроміограф “Нейро-ЕМГ-мікро”, автоматизована система аналізу прикусу “T-scan III” (“Tekscan”, США), апарат для визначення каріозних порожнин та твердих і м'яких під'ясенних зубних відкладень “Diagnodent” та аналізатор лазерної мікроциркуляції крові “Лакк-02”. Вказані прилади запускаються за допомогою програми реєстрації пацієнтів, розробленої працівниками університету, версія якої постійно поновлюється та вдосконалюється. Програма дозволяє об’єднувати роботу апаратів та проводити комплексні функціональні дослідження пацієнтів із виведенням наприкінці циклу роботи системи даних, що характеризують стан зубощелепної системи пацієнта та потребу у різних видах корекції стоматологічного статусу.

В НПЦ “Стоматологія” розпочато роботу із впровадження найновіших технологій доповненої та віртуальної реальності на базі комплексу LeapMotion та спеціального програмного забезпечення, котрий дасть змогу під повним контролем викладача виробити у студентів навички, котрі раніше могли бути виконаними тільки на пацієнті.
Даний програмно-апаратний комплекс буде імплементований до комп’ютерного класу кафедри.

НПЦ “Фармація” об’єднує 5 лабораторій. Лабораторія практичної фармації № 1 дозволяє опанувати практичні навички $з$ дисциплін “Фармацевтична ботаніка”, “Фармакогнозія”, “Ресурсознавство лікарських рослин”, обладнана вагами, мікроскопами, хімічним посудом, гербаріями лікарських рослин, матеріалами для проведення хроматографії. Лабораторія практичної фармації № 2, де студенти набувають практичних навичок з дисциплін “Фармацевтична хімія”, “Стандартизація лікарських засобів”, обладнана рефрактометром, вагами, хімічним посудом, титрувальними установками, лікарськими речовинами та засобами. Лабораторія практичної фармації № 3 дозволяє опанувати практичні навички 3 дисциплін “Аптечна технологія лікарських засобів”, “Промислова технологія лікарських засобів”, “Технологія косметичних лікарських засобів”, “Біофармація”, “Технологія лікарських засобів”; обладнана вагами, берековими установками, фотометром ВТ-1000, рН-метром, машиною для виготовлення пілюль, електричними змішувачами, стерилізатором, електронним мікроскопом "DeltaOpticalGeneticPro" $з$ вмонтованою камерою (об’єктив 40/0,65 160/0.17; окуляр WF 10×/18), набір лабораторних сит, лабораторне обладнання. Організовано окремо НПЦ “Хроматографічний аналіз”, який обладнаний газовими хроматографами “Цвет-500”, “Цвет-100”, рідинним хроматографом “Міліхром-4”, спектрофотометрами “СФ-26”, КФЕК-2, КФЕК-2МП, термостатом “ЕС-80”. У лабораторії практичної фармації № 4 студенти оволодівають практичними навичками 3 дисциплін “Неорганічна хімія”, “Аналітична хімія”, “Органічна хімія”, “Фізколоїдна хімія”, “Токсикологічна хімія”. Лабораторія обладнана фотоколориметром, потенціометром, рефрактометром, спектрофотометром, кондуктометром, сахариметром, рН-метром, обладнанням для тонкошарової хроматографії. У лабораторії практичної фармації № 5 студенти та інтерни можуть опанувати практичні навички з таких дисциплін, як: “Організація та економіка фармації”, “Ознайомча практика 3 організації та економіки фармації”, “Фармакоекономіка”, “Фармацевтичне правознавство”, “Фармацевтичне та медичне товарознавство”, “Історія медицини і фармації”, “Менеджмент та маркетинг у фармації” та зі спеціалізацій: “Підприємництво у фармації”, “Організація та регулювання діяльності підприємств фармації”. Лабораторія обладнана 
аптечними меблями, згідно з вимогами чинного законодавства оформлені вітрини, стелажі, куток споживача в аптеці. Студенти мають можливість ознайомитись із бланками та зразками рецептів, їх правильним оформленням.

НПЦ “Фармація” розподілений на різних навчальних базах. Загальна площа 679,3 кв.м, розрахований на 155 посадочних місць, має 2 комп’ютерних класи загальною місткістю 25 студентів. Центр під’єднаний по безпровідному зв'язку до мережі університету та до всіх внутрішніх навчальних бібліотек.

Організація роботи в НПЦ університету дозволяє студентам опанувати практичні навички як під час практичних занять, так і самостійно згідно з графіком роботи центрів і консультацій викладачів. Методичне забезпечення НПЦ включає навчальнометодичні вказівки, нормативні документи, “Алгоритми виконання практичних навичок” українською, російською та англійською мовами, які допомагають студентам набути практичних вмінь. У кожному кабінеті є вся необхідна для його роботи документація: графік роботи, розклад занять, перелік практичних навичок, якими тут можна оволодіти (українською, російською та англійською мовами), алгоритми виконання цих навичок (трьома мовами).

\section{Список літератури}

1. Про впровадження Рішення наради ректорів вищих медичних (фармацевтичного) навчальних закладів IV рівня акредитації та закладів післядипломної освіти MO3 України “Підсумки проведення вступної кампанії до вищих навчальних закладів МОЗ України у 2011 році. Актуальні питання поліпшення якості та організації підготовки медичних та фармацевтичних спеціалістів” : наказ МОЗ України від 11.11.2011 р. № 782.

2. Навчальний план підготовки фахівців освітньокваліфікаційного рівня “спеціаліст” кваліфікації “лікар” у ВНЗ IV рівня акредитації за спеціальностями 7.110101 “Лікувальна справа”, 7.110104 “Педіатрія”. (2007, 2010 рр.)

3. Навчальний план підготовки фахівців освітньокваліфікаційного рівня “спеціаліст” кваліфікації “лікарстоматолог” у ВНЗ IV рівня акредитації за спеціальностями 7.110106 “Стоматологія”. (2007, 2010 рр.)

4. Навчальний план підготовки фахівців освітньокваліфікаційного рівня “спеціаліст” кваліфікації “провізор” у ВНЗ IV рівня акредитації за спеціальностями 7.110201 “Фармація”. (2007, 2010 рр.)

5. Медицинское образование в мире и в Украине / [Ю. В. Поляченко, В. Г. Передерий, А. П. Волосовец и др.]. - Харьков : ИПП “Контраст”, 2005. - 464 с.
3 метою якісного засвоєння студентами практичних навичок та повноцінного контролю за їх виконанням в університеті розроблено, відповідно до чинних державних стандартів медичної освіти та Наскрізної програми підготовки студентів медичних факультетів вищих медичних навчальних закладів IV рівня акредитації та лікарів-інтернів для оволодіння практичним навичками та методиками, необхідними для роботи на посадах лікарів за спеціальністю “Загальна практика - сімейна медицина”, схвалено Вченою радою і введено в дію наказом ректора для студентів за спеціальностями “Лікувальна справа” та “Педіатрія” “Індивідуальний план практичної підготовки студента” [2-4]. Наразі розроблено та планується до впровадження Індивідуальний план практичної підготовки студента для студентів, які навчаються за спеціальністю “Стоматологія”.

Висновок. На нашу думку, розвиток системи навчально-практичних центрів з належним матеріальним, методичним та інформаційним забезпеченням є одним із шляхів реалізації компетентнісного підходу в підготовці майбутніх фахівців медичної та фармацевтичної сфери.

6. Кремень В. Г. Нові вимоги до якісної освіти / В. Г. Кремень // Освіта України. - 2006. - № 45-46. C. 6-7.

7. Ситуаційна методика навчання: теорія і практика. К. : Центр інновацій та розвитку, 2001. - С. 8-10.

8. Драч I. І. Компетентнісний підхід як засіб модернізації змісту вищої освіти / I. I. Драч // Проблеми освіти: наук. зб. / [кол. авт.]. - К. : Інститут інноваційних технологій і змісту освіти МОН України, 2008. - С. 44-48.

9. Кодлюк Я. П. Компетентнісний підхід у підготовці майбутніх педагогів як пріоритет модернізації вищої освіти України / Я. П. Кодлюк // Компетентнісний підхід у сучасній освіті: світовий досвід та українські перспективи: Бібліотека з освітньої політики / за заг. ред. О. В. Овчарук. - K. : K.I.C., 2004. - С. 10-110.

10. Національний освітній глосарій: вища освіта / Miністерство освіти і науки України, Національна академія педагогічних наук України, Національний Темпус-офіс в Україні. - 2-ге вид., переробл. і доповн. Видання здійснено в рамках проекту Європейського Союзу “Національний Темпус-офіс в Україні”, що реалізується ГО “Інститут лідерства, інновацій та розвитку”. - К., 2014.

Отримано 06.04.16 